\title{
Wake Up, We're Being Green-Washed!
}

I'm sorry to report that the Bush Administration is using ecological restoration to cover-up or "green-wash" its many serious environmental shortcomings. What has become clear to me is, while the President walks among the wildflowers and little bluestem that he and the First Lady have had planted on their Texas ranch and while he promotes the restoration of wetlands like the Everglades, the country's environmental infrastructure is being underfunded, neglected, or destroyed.

I know the Bush Administration and its supporters will argue that the President and the Republican-controlled Congress have made continued progress in providing a better environment and improving public health. They would no doubt cite as their accomplishments: the 2002 Farm Bill with its various conservation programs, the Healthy Forests Act and its potential to reduce the threat of catastrophic wildfires in the western United States (see ER 21(1):7-41), the introduction in Congress of the Clear Skies Initiative, initiatives to restore marine ecosystems administered by the National Park Service, a proposal to increase funding for cooperative conservation programs managed by the Department of Interior, and tax initiatives for renewable energy technologies, including hybrid and fuel-cell vehicles.

I agree that many of these are laudable goals and that they reach to find that delicate, and often difficult, balance between political will and political reality. Nevertheless, I am left to wonder what do these proposals, initiatives, and pieces of legislation really mean and what will be the long-term results? Important questions, I would suggest, especially when reviewing the activities of a president and an administration that pride themselves on results rather than process.

I found it instructive to look a bit deeper into the Administration's environmental transactions to see if any patterns develop, whether consistencies occur, and what people close to the action have to say about the Bush environmental agenda and its accomplishments.

Let me begin with the reaction to the President's 2004 Earth Day announcement that the United States would strive to go beyond a no-net-loss wetland policy and towards a net gain of wetlands because I believe it goes to the heart of using ecological restoration as political cover. After he and his brother, Florida Governor Jeb Bush, helped volunteers remove invasive Brazilian peppertree and Australian pine at Rookery Bay National Estaurine Research Reserve near Naples, Florida, the President told the crowd, "My administration will work to restore, to improve, and to protect at least three million acres of wetlands over the next five years"- the same statement he made at another Earth Day event in Wells, Maine. After reviewing the President's speech, the National Wildlife Federation was quick to point out that the country is nowhere near attaining the goal of "no-net-loss" of wetlands. Their spokesperson pointed out that if we know anything about the nation's wetlands, it is that the United States will likely continue to lose wetland acreage. Indeed, planning officials from the Environmental Protection Agency recently estimated that the loss will be as much as 100,000 acres of wetland annually. Moreover, there seems to be little evidence that restorative activities will be enough to overcome such a deficit, especially when programs, such as the Wetland Reserve Program, remain underfunded. We also have to continue to ask and study whether restored wetlands fully replace wetlands that have been damaged or destroyed. Simply assuming that they do-as this administration does-is a serious error. Finally, the administration's general disdain for the Clean Water Act is also expected to hamper any realistic efforts to put the amount of wetland acreage in positive territory. Julie Sibbing, a wetlands policy analyst at the National Wildlife Federation, put it this way, "The administration's current policies, including a directive removing protection from an estimated 20 million acres of wetlands under the Clean Water Act, virtually guarantee that our country will continue to lose both wetland function and acreage."

Also on Earth Day 2004, nearly one hundred leaders of Christian groups from across the country sent the President a letter expressing their concern with the administration's environmental policies, especially the Clear Skies Initiative. Their letter begins, "In a spirit of shared faith and respect, we feel called to express grave moral concern about your "Clear Skies" initiative-which we believe is The Administration's continuous effort to weaken critical environmental standards that protect God's creation." The letter goes on to say "Respected scientific estimates, some by the federal government itself, cause us to question whether this "Clear Skies" proposal meets fundamental moral responsibilities as set out by the Bible." Why are these ministers and priests joining others in expressing their concern about clean air? Quite simply because the Clear Skies Initiative would amend provisions of the Clean Air Act with respect to emissions limitations and set up free-market trading in emissions that would virtually do away with the current policy of regulation and enforcement, resulting in what many believe will be weaker air pollution standards. The White House has not responded to the 
letter, and the legislation (The Clear Skies Act of 2003, H.R. 999 and S. 485) remains in Congress.

In December 2003, the President signed The Healthy Forest Restoration Act into law. The legislation quickly made its way through Congress during a summer of intense wildfires throughout the western United States. While I support the thinning of over-stocked, fire-prone forests, I think that the administration has made critical errors in developing the rules for the implementation of this new law. For example, the Forest Service is now considering several steps to accelerate their work in this area. If adopted, the Service would no longer consult with the Fish \& Wildlife Service (FWS) and National Oceanic and Atmospheric Administration Fisheries (NOAA) about inland aquatic species and, building on an administrative rule waiving Endangered Species Act consultation on fire-related activities, would expand this no consultation "to all land management activities." In addition, they would no longer analyze the environmental effects of any herbicide application done to control invasive plants or comply with Historic Preservation Act rules requiring review by state agencies of historical and cultural artifacts. This suggests to me that the administration's emphasis on results has come at the price of disregarding important oversight processes and crucial public participation.

Meanwhile, NOAA Fisheries officials have decided to determine the health of the Pacific Northwest salmon run by counting hatchery raised salmon as well as wild salmon. This decision, which was made despite recommendations to the contrary from their own advisory panel of six leading salmon experts, may cause some of the 26 native stocks of Pacific salmon to be removed from endangered species status. Echoing the sentiments of many critics, Senator Maria Cantwell of Washington said, "I'm very concerned that we're moving away from science, which is what our policy has been based on, for some political judgment or political expediency." Curiously enough, NOAA Fisheries is also under a federal court order to rewrite the Northwest's salmon protection plan by September 15, 2004.

In Florida, aside from the recent rumblings about the pace of restoration in the Everglades (ER 22(2):84), concerns have been raised about the endangered Florida panther. Andrew Eller, Jr., a biologist with FWS for 17 years, and Public Employees for Environmental Responsibility (PEER) have filed a legal complaint with the agency that cites the FWS with inflating Florida panther populations and minimizing panther habitat requirements. Jeff Ruch, executive director of PEER, says, "These scientific problems have been known for years ... but to correct them would require that the Service actually object to mega-developments in the western Everglades. The FWS is under severe pressure from its political superiors to commit scientific fraud to avoid inconveniencing campaign contributors."

A bit further west, BNP Petroleum of Texas has begun drilling natural gas wells in Padre Island National Seashore, with the blessing of the National Park Service (NPS) — an agency that has recently issued its park superintendents "talking points" to use when communicating with the media about budgets and other park-related issues. The drilling has occurred without consulting the FWS about the populations of Kemp's ridley sea turthe that live in the area, as required by the Endangered Species Act. In addition to extracting resources from public land, the drilling puts in jeopardy 25 years of work by NPS to restore this turtle species. Of course, the Bush Administration has made it no secret that it would allow oil drilling in the Artic Wildlife Refuge, an action that would complement their decision to open roadless areas of old-growth in national forests, including the Tongass National Forest, to logging.

And in southern California, the California Native Plant Society (CNPS) has felt it necessary to join in a lawsuit against the U.S. Department of Homeland Security, which wants to build a border fence and roads across miles of rare coastal mesa habitat in San Diego County. Cory Briggs, the attorney for CNPS and the other litigants said, "Not only have they [USDHS] done a feeble job in reviewing the project's adverse environmental impacts, but when the inadequacies were pointed out, they responded as if they're not bound by the law."

I do find it heartening that the President is growing native grasses and forbs at his ranch, and that he feels this sort of activity makes his family feel they are enhancing "their little piece of heaven." And I am likewise pleased and hopeful about the positive activities that have occurred under this administration's watch in the name of ecological restoration, like the Team Tamarisk meeting I recently attended in Albuquerque, New Mexico. But those actions must be seen against the much larger negative effects of other policies that continue to exploit the nation's natural capital. This imbalance is not only unhealthy in ecological terms, it rekindles the old warnings that ecological restoration would only serve to justify the destruction of what the powerful desired.

Ecological restorationists, in general, and SER International, in particular, need to wake up and admit the practice they hold dear is being co-opted by those who-wittingly or not-would use restoration to greenwash their environmental missteps. As Keith Bowers suggests in this issue, we need to become more active in setting recognizable and reliable standards for ecological restoration. We also have to be willing and able to discuss the ethical implications of restoration activities as they relate to the rest of the environment and society. We must remember that "do no harm" should be our first principle of operation, and not fall into the trap of seeing our work as a new-growth economy. We must educate both tomorrow's and today's policymakers about restoration, and be willing to talk with political officials and testify before government bodies to explain our vision of ecological restoration. Ecological restoration is ecologically and socially important, but it must not be allowed to be the window dressing-the lovely green landscaping-that hides an otherwise crumbling environment.

\section{Dave Egan}

